\title{
Selection of plant growth-promoting bacteria in sweet sorghum (Sorghum bicolor (L.) Moench) under the effects of salinity
}

\author{
Marta Amâncio do Nascimento ${ }^{1,2^{*}}$, Carlos Vinicius do Nascimento ${ }^{3}$, Jadson Emanuel Antunes ${ }^{1}$, \\ Márcia do Vale Figueiredo ${ }^{1}$, José Nildo Tabosa', Cosme Rafael Martínez ${ }^{2,3}$ \\ From 5th Congress of the Brazilian Biotechnology Society (SBBIOTEC) \\ Florianópolis, Brazil. 10-14 November 2013
}

\section{Background}

Sorghum, a grassy non-halophyte, it is both drought and salinity tolerant, and is considered a promising crop for semiarid regions. During the last 20 years, its culture has expanded in Brazilian production by $780 \%$, reaching $1,928,970$ tons in 2009 [1]. Salinization of the soil and lack of rain are increasing constraints in semiarid regions. They predominate in northeastern Brazil. This has helped limit the production of plant biomass, which is the basis of agricultural activity. The advantages of sorghum in these conditions can be improved still further by using plant growth-promoting bacteria (PGPB) for the biological processes of nitrogen fixation, and hormone production, as well as others [2]. Endophytic bacteria can secrete up to one half of the nitrogen they fix, and plants may then assimilate the nitrogen efficiently [3]. Inoculation with Azotobacter chroococcum has been shown to attenuate stress in maize grown in saline soil [4]. In this study, we evaluated the action of PGPB on a "Wray" saccharine variety with low salinity tolerance.

\section{Methods}

The experiment used a factorial arrangement $(2 \times 10)$ with two blocks. The salinity conditions were 8 and $75 \mathrm{mM}$ $\mathrm{NaCl}$ (Hoagland solution - SH). The isolates tested were Herbaspirillum seropedicae (Hs08 and Hs09), Burkholderia vietnamiensis (Bv12), B. phymatum (Bp16), H. seropedicael Burkholderia spp. (Hs/B30), and Burkholderia spp. (B62). All were tested with inorganic nitrogen $(\mathrm{N})$ at $4 \mathrm{mM}$, and un-inoculated treatments of inorganic $\mathrm{N}$ at $2,4,8$, and

'IPA Instituto Agronômico de Pernambuco - Av. Gen. San Martin, 1371, Bongi, 50761-000, Recife-PE, Brazil

Full list of author information is available at the end of the article
$16 \mathrm{mM}$. The bacteria were isolated in the state of Paraíba Brazil. Disinfected seeds were sown in sterile sand $+\mathrm{SH}$ (pH 6.5), and inoculated with standardized bacterial suspensions $\left(A_{600}=0.500\right)$. The plants were grown (35 days) in a growth chamber under controlled conditions.

\section{Results and conclusions}

Compared to the controls $(4 \mathrm{mM} \mathrm{N})$, significant increases in shoot biomass SB (3x), transpiration $\mathrm{T}(3 \mathrm{x})$, and root biomass RB $(2 \mathrm{x})$ were observed (when $\mathrm{N}$ increased under non-saline conditions). Plant height $\mathrm{PH}$ response was lower $(1.2 \mathrm{x})$. However, under saline conditions, the inorganic $\mathrm{N}$ induced significant and varied reductions $(-0.2 x$ in $\mathrm{PH},-0.3 \mathrm{x}$ for $\mathrm{SB},-0.5 \mathrm{x}$ for $\mathrm{RB}$ and $-0.4 \mathrm{x}$ for $\mathrm{T})$. We found specific relationships between the bacteria used and both the plant's growth, and sensitivity to salinity. The isolate Hs09 in non-saline conditions provided an $\mathrm{T}$ and an $\mathrm{SB}$ equivalent to those obtained at $8 \mathrm{mM} \mathrm{N}$. However, the greatest benefits were seen for $\mathrm{PH}$ and $\mathrm{RB}$. Under saline conditions, Bp16 induced 2x higher SB, BR, and T, and 1.2x higher $\mathrm{PH}$ than in the control. Inoculations with $\mathrm{Hs} 08$, and Bp16 significantly improved $\mathrm{SB}, \mathrm{T}$, and thus the Wray salinity tolerance. Perhaps the action of hormones, improved nutritional status, or osmo-regulation induced by the bacteria-plant interaction may have contributed to this performance [2-4]. The stability of the PGPB action for $\mathrm{Hs} 09, \mathrm{Hs} 08$, and $\mathrm{Bp} 16$, and their attenuation of stress (Hs08 and Bp16) must be tested in other varieties, and saline soils to validate the use of this biotechnological factor for sustainable production of sorghum in saline environments. 


\section{Acknowledgements}

Brazilian Ministry of Science and Technology - CNPq - Brazil, Coordination of Improvement of Higher Education Personnel - CAPES - Brazil.

\section{Authors' details}

'IPA Instituto Agronômico de Pernambuco - Av. Gen. San Martin, 1371, Bongi, 50761-000, Recife-PE, Brazil. Pós-Graduação em Biotecnologia - UFPB - RENORBIO, Brazil. ${ }^{3}$ UFPB Universidade Federal da Paraíba, Departamento de Química - Cidade Universitária, 58051-900, João Pessoa-PB, Brazil.

Published: 1 October 2014

\section{References}

1. Brazilian Institute of Geography and Statistics Database. [http://www. sidra.ibge.gov.br].

2. Pérez-Alfocea F: Microbial amelioration of crop salinity stress. J Exp Bot 2012, 63(9):3415-3428.

3. Döbereiner J: A importância da fixação biológica de nitrogênio para a agricultura sustentável. Biotecnolog Cienc Desenvolv 1997, 1(Special Suppl).

4. Rojas-Tapias D, Moreno-Galván A, Pardo-Díaz S, Obando M, Rivera D,

Bonilla R: Effect of inoculation with plant growth-promoting bacteria (PGPB) on amelioration of saline stress in maize (Zea mays). ApplSoilEcol 2012, 61:264-272.

doi:10.1186/1753-6561-8-S4-P113

Cite this article as: do Nascimento et al: Selection of plant growthpromoting bacteria in sweet sorghum (Sorghum bicolor (L.) Moench) under the effects of salinity. BMC Proceedings 2014 8(Suppl 4):P113.

\section{Submit your next manuscript to BioMed Central and take full advantage of:}

- Convenient online submission

- Thorough peer review

- No space constraints or color figure charges

- Immediate publication on acceptance

- Inclusion in PubMed, CAS, Scopus and Google Scholar

- Research which is freely available for redistribution

Submit your manuscript at www.biomedcentral.com/submit 